\title{
Effect of different nitrogen/phosphorus nutrient ratios on the toxin content in Alexandrium minutum
}

\author{
Christian Béchemin ${ }^{1, *}$, Daniel Grzebyk ${ }^{1}$, Fatima Hachame ${ }^{1}$, Christian Hummert ${ }^{2}$, \\ Serge Y. Maestrini ${ }^{1}$
}

${ }^{1}$ Centre de Recherche en Ecologie Marine et Aquaculture de L'Houmeau (CNRS-IFREMER), BP 5, 17137 L'Houmeau, France

${ }^{2}$ Institute of Nutrition and Environment, University of Jena, Dornburger Str. 25 07743 Jena, Germany

\begin{abstract}
Alexandrium minutum (strain AM89BM) was grown in semi-continuous culture (0.2 volume $\left.\mathrm{d}^{-1}\right)$ in $\mathrm{N}$-limiting $\left(\mathrm{NO}_{3}: \mathrm{PO}_{4}=1.6\right.$ and 3.16), in P-limiting $(\mathrm{N}: \mathrm{P}=160$ and 80$)$, and in $\mathrm{N}$ - and $\mathrm{P}$-balanced $(\mathrm{N}: \mathrm{P}=16)$ media. Daily supplies of limiting nutrients were taken up until exhaustion; most residual concentrations before renewal were near the detection limits. Samples were taken during 2 separate periods: Days 5 to 12 and 26 to 36. During both periods, cells grew at the real rates of 0.23 division $\mathrm{d}^{-1}$ in the $\mathrm{N}: \mathrm{P}$ balanced medium, while the growth rate was decreased in all $\mathrm{N}: \mathrm{P}<16$ or $>16$ media during the first period, and only in the $N: P=1.6$ medium during the second period. Cells grown in $N$ limiting media contained $1 / 3$ less PON and $1 / 2$ less chlorophyll a than cells grown in the N:P balanced condition. The POP content per cell did not vary significantly. In contrast, PON:POP ratios in cells grown in P-limiting conditions were over 50. Thus, cells grown in the $2 \mathrm{~N}$ :P $<16$ conditions were nitrogen-deficient, while cells grown in $\mathrm{N}: \mathrm{P}=80$ and 160 conditions were nitrogen-surfeit. The toxin content in cells greatly changed according to the N:P regime. Cells grown at N:P balanced conditions showed an average total paralytic shellfish poisoning (PSP) content of $1.24 \mathrm{fmol}^{\text {cel }}{ }^{-1}$ In N-limiting conditions, cells contained ca 3 times less toxin, with mean values of 0.41 to $0.45 \mathrm{fmol}_{\text {cell }}^{-1}$. In contrast, cells grown in P-limiting conditions contained on average 3.5 and 7 times more toxins than under balanced $\mathrm{N}: \mathrm{P}$ conditions; $4.31 \mathrm{fmol} \mathrm{cell}^{-1}$ in the $\mathrm{N}: \mathrm{P}=160$ medium and $8.01 \mathrm{fmol}^{\mathrm{c}} \mathrm{cll}^{-1}$ in the $\mathrm{N}: \mathrm{P}=80$ medium.
\end{abstract}

KEY WORDS: Alexandrium minutum $\cdot$ Toxin content $\cdot$ PSP $\cdot$ Nitrogen deficiency $\cdot$ Nitrogen excess

\section{INTRODUCTION}

Human activities have significantly increased the input of nitrogenous and phosphorus nutrients to estuarine and coastal waters, while the silicon concentration has remained constant or has even decreased in river discharges as a result of large blooms of freshwater diatoms stimulated by the loading of nitrogen and phosphorus in inland waters (Schelscke \& Stoermer 1972, Egge \& Aksnes 1992). Hence, by and large,

\footnotetext{
•E-mail: cbechemi@ifremer.fr
}

along with increased eutrophication in coastal waters N:Si and P:Si ratios have increased (Conley et al. 1993, Ragueneau et al. 1994, Rahm et al. 1996), thus favouring the proliferation of organisms having little or no requirement for silicon such as flagellates and cyanobacteria (Sandén \& Håkansson 1996, Schöllhorn \& Granéli 1996, Balode et al. 1998, Dippner 1998, Wasmund et al. 1998). In addition to influencing species dominance and succession, nutrient ratios influence the biochemical composition of cells (Healey \& Hendzel 1979, Sakshaug et al. 1984, Brzezinski 1985, Flynn et al. 1993). This has thus led to the question of whether or not balanced or unbalanced nutrient avail- 
ability would also change the toxin production in toxic algae. Hence, enhanced production of the paralytic shellfish poisoning (PSP) toxins, saxitoxins, under phosphorus deficiency has been observed in both the Pacific dinoflagellate Protogonyaulax (Alexandrium) spp. (Hall 1982 fide Boyer et al. 1987) and the Atlantic species Alexandrium fundyense and A. tamarense (Anderson et al. 1990). In addition, Matsuda et al. (1996) demonstrated that both toxin content per cell and net toxin production rates decreased as the cell quota for nitrogen decreased in A. catenella under nitrogen deficiency.

In this study, we tested the influence of P-limiting and $\mathrm{N}$-limiting conditions on the toxin content in Alexandrium minutum grown in semi-continuous culture.

\section{MATERIAL AND METHODS}

The clonal culture of Alexandrium minutum, strain AM89BM, was isolated from a temporary cyst in 1989 by Dr E. Erard-Le Denn from the Bay of Morlaix, Brittany, France, where PSP outbreaks have been observed since 1985 . The stock culture was grown in a medium which is based on the $F$ medium of Guillard \& Ryther (1962), except for the N:P ratio which was made equal to Redfield's (1934) value (16) and for iron which was added in the form of Fe-EDTA. Cells were collected in the upper layer of a $20 \mathrm{l}$ culture and transferred for $7 \mathrm{~d}$ in a medium with no addition of nitrogenous and phosphorous compounds. Depleted cells were again collected in the upper layer of the culture while obviously swimming.

Seawater for the preparation of the culture media was collected offshore (salinity 35) (French Atlantic coast), filtered on $0.22 \mu \mathrm{m}$ cartridge (Opticap ${ }^{\mathrm{TM}}$ Cartridge, Millipore), then heated at $80^{\circ} \mathrm{C}$ for $10 \mathrm{~min}$. After cooling, the Fe-EDTA solution and the metal and vitamin mixtures were added, plus $80 \mathrm{mg} \mathrm{l}^{-1} \mathrm{NaHCO}_{3}$, in order to compensate for the loss of $\Sigma \mathrm{CO}_{2}$. This enriched seawater was then aseptically filtered through a $0.2 \mu \mathrm{m}$ membrane filter and distributed $(4 \mathrm{l})$ into $5 \mathrm{l}$ polycarbonate preautoclaved bottles (Nalgene). Nitrogen and phosphorus were aseptically added, according to different treatments, by using autoclaved-sterile solutions.

Five N:P regimes were established, each in 5 replicates: phosphorus limitation ( $\mathrm{N}: \mathrm{P}=160$ and 80 with $\left.60 \mu \mathrm{M} \mathrm{NO}_{3}\right)$, balanced $\mathrm{N}$ and $\mathrm{P}$ condition $(\mathrm{N}: \mathrm{P}=16$ with $60 \mu \mathrm{M} \mathrm{NO} \mathrm{N}_{3}$ and with $3.8 \mu \mathrm{MPO}_{4}$ ), nitrogen limitation $\left(\mathrm{N}: \mathrm{P}=3.16\right.$ and 1.6 with $\left.3.8 \mu \mathrm{MPO}_{4}\right)$. Then the depleted cells of Alexandrium minutum were inoculated; $2.73 \times 10^{6}$ cells in $150 \mathrm{ml}$ were added to each bottle, providing an initial concentration of $682 \times 10^{3}$ cells $\mathrm{l}^{-1}$. The cultures were grown at $18 \pm 1^{\circ} \mathrm{C}$, with a
16:8 $\mathrm{h}$ light:dark photoperiod at $53 \mu \mathrm{mol} \mathrm{m}^{-2} \mathrm{~s}^{-1}$ irradiance from cool white fluorescent tubes.

The cultures were run as batch cultures for $5 \mathrm{~d}$. Thereafter, a semi-continuous culture regime was established $\left(0.2\right.$ volume $\left.\mathrm{d}^{-1}\right)$. For practical constraints (new water supply) the semi-continuous culturing was stopped from Day 14 to Day 23, and nutrients ( $\mathrm{N}$ and $\mathrm{P}$ ) were supplied (1.5-fold the initial concentrations in the $\mathrm{N}: \mathrm{P}=16$ condition, 2.3 times in the other conditions) in order to sustain growth in the batch regime for $1 \mathrm{wk}$; then, 21 were removed from each culture and replaced by seawater, and after analysis of the nutrient concentrations, initial concentrations were re-established. On Day 23, the dilution rate was re-established. In practice, the experiment evolved as 2 successive experiments. After establishment of the dilution regime, sampling was delayed for $4 \mathrm{~d}$, in order to allow the cell content to stabilise. On Days 9, 10, 11, 12, 27, 29, 33 and 36 , the removed culture fractions were used for analyses. Subsamples for toxin analyses were taken in all these fractions; subsamples for biomass analyses were taken in all but 2 fractions: on Days 10 and 11 .

Inorganic nutrient concentrations were measured immediately after sampling using manual protocols: nitrate, reduction to nitrite according to the protocol of Strickland \& Parsons (1972); nitrite, method of Bendschneider \& Robinson (1952); ammonium, method of Koroleff (1976); phosphate, method of Murphy \& Riley (1962). Detection limits: $\mathrm{NO}_{3}-\mathrm{NO}_{2}, 0.01 \mu \mathrm{M} ; \mathrm{NH}_{4}$, $0.05 \mu \mathrm{MPO}_{4}, 0.02 \mu \mathrm{M}, \mathrm{SiO}_{3}, 0.1 \mu \mathrm{M}$ (Aminot \& Chaussepied 1983).

In vivo fluorescence was monitored with a $10 \mathrm{AU}$ Turner Fluorometer (Brand et al. 1981). Samples $(2.6 \mathrm{ml})$ for Alexandrium minutum cell counting (Utermöhl 1931) were fixed with acid Lugol's solution. Samples $(18 \mathrm{ml})$ for bacteria counting were fixed with $2 \mathrm{ml}$ $\mathrm{pH}=7$ formalin; after addition of DAPI (Porter \& Feig $1980)$ and filtration onto black $0.2 \mu \mathrm{m}$ membrane Nuclepore filters, bacteria were counted with an epifluorescence microscope (Coleman 1980). For estimation of biovolume, the DAPI-stained cells were photographed (Kodak Ektachrome 400; exposed as Iso 1600); a Leitz Dialux epifluorescence miscroscope fitted with a $100 \times$ 1.25 objective was used. Photographs were projected onto a screen and cell dimensions were measured by comparison with a photograph of a calibrated micrometer. Cells were classified into spheres (volume $=4 / 3$ $\pi r^{3}$ ) and rods (cylinders with hemispherical caps, volume $\left.=\pi r^{2}[L-2 / 3 r]\right)$. The carbon content was esti-

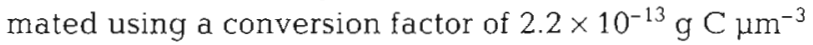
(Bratbak \& Dundas 1984). Chlorophyll a (chl a) (Yentsch \& Menzel 1963) was determined after filtration through glass microfibre filters (Whatman GF/F $0.7 \mu \mathrm{m}$ equivalent), and extraction with $6 \mathrm{ml}$ pure methanol, at $4^{\circ} \mathrm{C}$, for $1 \mathrm{~h}$ in the dark. Samples for par- 
ticulate organic carbon (POC) and particulate organic nitrogen (PON) were collected on precombusted glass microfibre filters Whatman GF/F, then decarbonated ( $\mathrm{HCl}$ fumes, overnight), and analysed by using a CHN analyser, model 1500 from Carlo Erba. Particulate organic phosphorus (POP) was collected on glass microfibre filters Whatman $\mathrm{GF} / \mathrm{F}$ initially washed in $\mathrm{HCl}$ $10 \%$ rinsed with deionized water, dried and combusted $\left(450^{\circ} \mathrm{C}\right.$ for $\left.4 \mathrm{~h}\right)$. After a wet-oxidation procedure with a persulfate digestion at $120^{\circ} \mathrm{C}$ (Pujo-Pay \& Raimbault 1994) phosphate concentrations in the digested sample were determined using an automated colorimetric technique on a Skalar Auto Analyser.

Cells for toxin analyses were collected by filtration onto precombusted glass microfibre filters Whatman $\mathrm{GF} / \mathrm{F}$, then stored at $-20^{\circ} \mathrm{C}$ until analysis. Before extraction, filters were dried at $37^{\circ} \mathrm{C}$ for $48 \mathrm{~h}$. Toxins were extracted with $1 \mathrm{ml}$ of $0.03 \mathrm{~N}$ acetic acid applying a probe sonicator (1 min); after centrifugation (10 min, $2980 \times g)$, the supernatant was filtrated through a $0.45 \mu \mathrm{m}$ nylon membrane filter. An aliquot of the $0.03 \mathrm{~N}$ acetic acid raw extract $(150 \mu l)$ was mixed with hydrochloric acid $(1.0 \mathrm{~N}, 37 \mu \mathrm{l})$ and heated in a sealed vial for 15 min to convert N-sulfocarbamoyl toxins into their related carbamoyl toxins. After cooling to room temperature, the reaction solution was neutralized with sodium acetate solution $(1.0 \mathrm{~N}, 75 \mu \mathrm{l})$. The hydrolysed extracts were stored at $-20^{\circ} \mathrm{C}$ until analysis, within a period not exceeding $24 \mathrm{~h}$. Both the raw extracts obtained with $0.03 \mathrm{~N}$ acetic acid as well as the hydrolysed raw extracts were analysed in independent chromatographic runs, using a HPLC method recently described by Hummert et al. (1997) and then slightly modified by Yu et al. (1998).

\section{RESULTS}

The respective daily supply of limiting nutrients was taken up until exhaustion: most residual concentrations of limiting nutrients in sampled cultures before refilling with new media were in the range of the detection limits. In the $\mathrm{N}: \mathrm{P}=16$ condition, residual concentration of $\mathrm{NO}_{3}$ was also near the detection limit, whereas mean concentration of remaining $\mathrm{PO}_{4}$, though very low, was significantly higher than the detection limit.

In all cultures, during the initial batch period, the in vivo fluorescence increased quickly after inoculation, thus showing active growth. During the first semi-continuous dilution period, the in vivo fluorescence remained almost constant in cultures grown in the $\mathrm{N}: \mathrm{P}=16$ treatment, while it decreased in all other cultures; the highest decrease occurred in the N:P $=1.6$ cultures. During the second semi-continuous culture
Table 1. Mean actual division rate $\left(\mathrm{d}^{-1}\right)$ during the first semicontinuous-culturing period (Days 5 to 12) and the second semi-continuous-culturing period (Days 26 to 36) of Alexandrium minutum grown in the 5 different N:P treatments

\begin{tabular}{|lcc|}
\hline Treatment $(N: P)$ & Days 5-12 & Days 26-36 \\
\hline 160 & -0.02 & 0.22 \\
80 & 0.10 & 0.22 \\
16 & 0.23 & 0.23 \\
3.16 & 0.08 & 0.21 \\
1.6 & 0.07 & 0.14 \\
\hline
\end{tabular}

period, the in vivo fluorescence varied very little in all cultures, except in the more nitrogen-limiting treatment ( $N: P=1.6)$, in which it decreased.

On the whole, cell concentrations somewhat decreased over time in all cultures; they slightly varied in the $\mathrm{N}: \mathrm{P}=16$ condition, whereas the decrease was larger in the phosphorus-limiting conditions. The highest cell concentration was recorded in the $\mathrm{N}: \mathrm{P}=16$ condition. During the first semi-continuous period, the mean 5 replicate values decreased from $7.38(\mathrm{SD}=0.25)$ to $5.34 \times 10^{6}$ cells $^{-1}(\mathrm{SD}=0.18)$, and from $12.43(\mathrm{SD}=0.32)$ to 5.00 ( $\mathrm{SD}=0.22)$ during the second period. The lowest cell concentrations were recorded in the most phosphorus-limiting media $(\mathrm{N}: \mathrm{P}=160)$; mean values varied from $2.74(\mathrm{SD}=0.41)$ to $0.53 \times 10^{6}$ cells $^{-1}(\mathrm{SD}=0.08)$ from Day 5 to Day 12, whereas from Day 26 to Day 36, the values decreased from $1.98(\mathrm{SD}=0.58)$ to $0.91 \times 10^{6} \mathrm{cells}^{-1}$ $(\mathrm{SD}=0.24)$.

Altogether, the theoretical division rate $(0.32$ division $\mathrm{d}^{-1}$ ) was not sustained in any culture. In the N:P $=16$ media, the growth rate was the highest and the same for both periods (Table 1). During the first semi-continuous dilution period, Alexandrium minutum did not grow at all in the $\mathrm{N}: \mathrm{P}=160$ medium, whereas its division rate versus that in the $\mathrm{N}: \mathrm{P}=16$ medium was decreased from 43 to $30 \%$ in the N:P $=80,3.16$ and 1.6 media. During the second period, all populations grew at a rate ranging from 0.21 to 0.23 division $\mathrm{d}^{-1}$, except in the $\mathrm{N}: \mathrm{P}=1.6 \mathrm{con}$ dition, where the division rate was ca $2 / 3$ slower.

Overall, the cell content greatly varied according to the N:P growth conditions, except for phosphorus, whereas differences between the first and second semi-continuous culturing periods were small. Cells growing in phosphorus-limited conditions $(\mathrm{N}: \mathrm{P}=80$ and 160 ) contained 2 to 3 times more carbon and nitrogen and $2 / 3$ more chl a than cells grown in N:P balanced conditions (Table 2 ). In contrast, cells which grew in nitrogen-limiting conditions (N:P $=3.16$ and 1.6) contained $1 / 3$ less nitrogen (Table 3 ) and $1 / 2$ less chl $a$. On the other hand, the phosphorus cell content did not vary significantly between the different $\mathrm{N}$ :P medium conditions. 

in Alexandrium minutum grown in different $N: P$ conditions, during the first semi-continuous-culturing period (Days 5 to $12 ; \mathrm{n}=10$ ), the second semi-continuous-culturing period (Days 26 to $36 ; n=20$ ), and both periods $(n=30)$. Numbers in parentheses are standard deviation

\begin{tabular}{|lrrrrrrr|}
\hline \multirow{2}{*}{ N:P } & \multicolumn{3}{c}{ POC (pmol cell ${ }^{-1}$ ) } & \multicolumn{3}{c|}{ Chlorophyll a $\left(\mathrm{pg} \mathrm{cell}{ }^{-1}\right)$} \\
& $\begin{array}{c}\text { Days } \\
\text { Days }\end{array}$ & All & \multicolumn{2}{c|}{ Days } & \multicolumn{2}{c|}{ Days } & All \\
& $5-12$ & $26-36$ & & $5-12$ & $26-36$ & \\
\hline 160 & $218(69)$ & $180(53)$ & $193(62)$ & $6.6(1.0)$ & $9.8(2.0)$ & $8.7(2.3)$ \\
80 & $145(27)$ & $144(26)$ & $144(27)$ & $6.9(0.8)$ & $9.2(1.2)$ & $8.5(1.6)$ \\
16 & $74(25)$ & $77(14)$ & $76(19)$ & $6.5(1.5)$ & $4.9(0.9)$ & $5.4(1.4)$ \\
3.16 & $79(30)$ & $82(08)$ & $81(19)$ & $3.3(1.4)$ & $2.8(0.4)$ & $2.9(0.9)$ \\
1.6 & $77(28)$ & $86(13)$ & $83(20)$ & $2.3(0.6)$ & $2.5(0.5)$ & $2.5(0.6)$ \\
\hline
\end{tabular}

Table 2. Mean particulate organic carbon (POC) and chlorophyll a cell contents

\section{DISCUSSION}

During the first dilution period, the growth rate of Alexandrium minutum was greatly reduced in the $4 \mathrm{~N}: \mathrm{P}$ unbalanced media, with no growth at all in the more phosphorus-limited condition. During the second dilution period, the growth rate compared to that in the $\mathrm{N}: \mathrm{P}=16$ condition was significantly reduced only in the more nitrogen-limiting condition. We have no hypothesis to explain these differences. Nevertheless, cell contents during the first and second periods were not significantly different, except for
Toxin concentrations in cells are given in Table 4. There were a few small differences between first and second semi-continuous culturing periods; hence, comments will refer only to pooled results. For the total PSP toxins, cells grown under N:P balanced conditions (N:P $=16)$ showed an average content of $1.42 \mathrm{fmol} \mathrm{cell}^{-1}$ ( $\mathrm{SD}=0.58, \mathrm{n}=34$ ). At the 2 higher $\mathrm{N}: \mathrm{P}$ ratios, the cell contents were 3.3 and 6.0 times higher than at the balanced N:P value, but the highest content was not recorded in the highest $N: P$ treatment. In the medium $\mathrm{N}: \mathrm{P}=160$, the toxin cell content was $4.68 \mathrm{fmol} \mathrm{cell}^{-1}(\mathrm{SD}=2.68, \mathrm{n}=31)$, whereas it peaked at $8.62 \mathrm{fmol} \mathrm{cell}^{-1}(\mathrm{SD}=3.38, \mathrm{n}=35)$ in the $\mathrm{N}: \mathrm{P}=80$ medium. At lower $\mathrm{N}: \mathrm{P}$ ratios, the cell contents were altogether ca 3 times lower than at $\mathrm{N}: \mathrm{P}=$ 16: $0.58 \mathrm{fmol} \mathrm{cell}^{-1}(\mathrm{SD}=0.50, \mathrm{n}=35)$ for $\mathrm{N}: \mathrm{P}=3.16$, and 0.42 fmol cell ${ }^{-1}(\mathrm{SD}=0.27, \mathrm{n}=36)$ for $\mathrm{N}: \mathrm{P}=1.6$. In these 2 treatments, however, the toxin content per cell was 2 to 4 times higher in cells grown during the second semi-continuous culturing period than during the first one.

GTX2 was the most abundant toxin in cells grown in all treatments; it represented between 50 and $64 \%$ of the total PSP content (Table 4); the lowest values, about $50 \%$, were recorded in the 2 media where N:P was $<16$, whereas the 2 highest values, between 59 and $63 \%$, were recorded in the 2 media where N:P $>16$. Percentages of GTX3 were also lower in the $2 \mathrm{~N}$-deficient media. The derivatives dcGTX2 and dcGTX3 showed opposite trends: the relative contents were higher in the $2 \mathrm{~N}: \mathrm{P}<16$ media than in the $\mathrm{N}: \mathrm{P}=16$ and the $2 \mathrm{~N}: \mathrm{P}>16$ media. Altogether, GTX3 and dcGTX3, representing between 32 and $43 \%$ of the total PSP toxins, were less present in cells than GTX2 and dcGTX2. chl $a$. In the 2 phosphorus-limiting conditions, the chl a content per cell was lower during the first period than during the second one, while it was higher in the N:P balanced treatment, and not significantly different in the nitrogen-limiting treatments (Table 2).

Since Redfield (1934) observed that $\mathrm{N}-\mathrm{NO}_{3}$ and $\mathrm{P}_{-} \mathrm{PO}_{4}$ are taken up by phytoplankton at a constant atomic ratio of $16: 1$, it has been commonly accepted that values $>16$ would reflect P-limiting conditions and values $<16$ would reflect $\mathrm{N}$-limiting conditions. Cells grown in nitrogen-limiting conditions showed a reduced nitrogen content per cell with regard to that of cells grown at $\mathrm{N}: \mathrm{P}=16$; the reduction was ca $2 / 3$ (Table 3 ). Moreover, the mean PON contents we recorded for the 2 nitrogenlimiting conditions, 5.1 and $5.5 \mathrm{pmol} \mathrm{cell}^{-1}$, were very close to the minimum nitrogen cell quota (sensu Droop 1974 ) in Alexandrium minutum ( $\left.3 \mathrm{pmol} \mathrm{cell}^{-1}\right)$ calcugrown in $\mathrm{N}: \mathrm{P}<16$ conditions showed both a growth rate limited by the availability of external nitrogen and a nitrogen-deficient cell content.

In contrast, the actual growth rate was significantly decreased in the 2 phosphorus-limiting conditions only during the first period. In addition, the phosphorus conlated by Flynn et al. (1996). Hence, we assume that cells

Table 3. Mean particulate organic nitrogen ( $P O N$ ) and particulate organic phosphorus (POP) cell contents in Alexandrium minutum grown in different $N: P$ conditions, during first semi-continuous-culturing period (Days 5 to $12 ; \mathrm{n}=10$ ), second semi-continuous-culturing period (Days 26 to $36 ; n=20$ ), and both periods $(\mathbf{n}=30)$. Numbers in parentheses are standard deviation

\begin{tabular}{|lrrrrrrr|}
\hline N:P & \multicolumn{3}{c}{ PON (pmol cell $\left.{ }^{-1}\right)$} & \multicolumn{3}{c|}{ POP (pmol cell $\left.{ }^{-1}\right)$} \\
& $\begin{array}{l}\text { Days } \\
5-12\end{array}$ & $\begin{array}{c}\text { Days } \\
26-36\end{array}$ & All & $\begin{array}{c}\text { Days } \\
5-12\end{array}$ & $\begin{array}{c}\text { Days } \\
26-36\end{array}$ & All \\
\hline 160 & $19.9(7.8)$ & $19.2(4.9)$ & $19.5(6.1)$ & $0.52(0.38)$ & $0.42(0.10)$ & $0.46(0.24)$ \\
80 & $14.3(3.3)$ & $17.6(2.6)$ & $16.5(3.3)$ & $0.19(0.06)$ & $0.33(0.08)$ & $0.28(0.11)$ \\
16 & $8.7(3.2)$ & $8.6(1.5)$ & $8.6(2.2)$ & $0.38(0.10)$ & $0.43(0.06)$ & $0.41(0.08)$ \\
3.16 & $4.8(1.9)$ & $5.8(0.8)$ & $5.5(1.3)$ & $0.33(0.14)$ & $0.30(0.04)$ & $0.31(0.09)$ \\
1.6 & $4.4(1.6)$ & $5.5(1.0)$ & $5.1(1.4)$ & $0.45(0.22)$ & $0.45(0.18)$ & $0.45(0.20)$ \\
\hline
\end{tabular}


Table 4. Mean toxin content (fmol) per cell in Alexandrium minutum grown in different N:P conditions, during the first semicontinuous-culturing period (Days 5 to 12), the second semi-continuous-culturing period (Days 26 to 36 , and both periods. $\%$ : mean relative (\%) concentration of the toxin (all cultures) versus the total PSP concentration. Numbers in parentheses are standard deviation

\begin{tabular}{|c|c|c|c|c|c|}
\hline \multirow[t]{2}{*}{ Period } & \multicolumn{5}{|c|}{ Treatment (N:P) } \\
\hline & 160 & 80 & 16 & 3.16 & 1.6 \\
\hline \multicolumn{6}{|l|}{ GTX2 } \\
\hline $5-12$ & $2.49(2.17)$ & $6.00(2.57)$ & $0.80(0.19)$ & $0.16(0.09)$ & $0.07(0.07)$ \\
\hline $26-36$ & $2.63(0.76)$ & $4.39(0.93)$ & $0.72(0.16)$ & $0.29(0.09)$ & $0.32(0.05)$ \\
\hline Both & $2.57(1.52)$ & $5.13(2.03)$ & $0.75(0.18)$ & $0.23(0.11)$ & $0.21(0.14)$ \\
\hline \multicolumn{5}{|l|}{ dcGTX2 } & 50.4 \\
\hline $5-12$ & $0.28(0.26)$ & $0.29(0.12)$ & $0.05(0.02)$ & $0.02(0.02)$ & $0.02(0.02)$ \\
\hline $26-36$ & $0.21(0.06)$ & $0.30(0.07)$ & $0.06(0.02)$ & $0.04(0.02)$ & $0.04(0.02)$ \\
\hline Both & $0.24(0.18)$ & $0.30(0.10)$ & $0.05(0.02)$ & $0.03(0.03)$ & $0.03(0.02)$ \\
\hline$\%$ & 5.5 & 3.7 & 4.3 & 7.0 & 7.3 \\
\hline \multicolumn{6}{|l|}{ GTX3 } \\
\hline $5-12$ & $0.69(0.61)$ & $1.83(0.86)$ & $0.22(0.05)$ & $0.06(0.06)$ & $0.02(0.02)$ \\
\hline $26-36$ & $0.83(0.28)$ & $1.24(0.40)$ & $0.26(0.09)$ & $0.09(0.05)$ & $0.09(0.04)$ \\
\hline Both & $0.77(0.45)$ & $1.51(0.71)$ & $0.24(0.08)$ & $0.08(0.06)$ & $0.06(0.05)$ \\
\hline \multicolumn{5}{|l|}{ dcGTX3 } & 14.5 \\
\hline $5-12$ & $0.67(0.67)$ & $0.78(0.31)$ & $0.10(0.03)$ & $0.06(0.05)$ & $0.05(0.05)$ \\
\hline $26-36$ & $0.79(0.16)$ & $1.32(0.50)$ & $0.26(0.14)$ & $0.17(0.09)$ & $0.16(0.02)$ \\
\hline Both & $0.74(0.45)$ & $1.07(0.50)$ & $0.20(0.13)$ & $0.12(0.09)$ & $0.11(0.07)$ \\
\hline$\%$ & 17.1 & 13.4 & 15.8 & 26.2 & 27.2 \\
\hline \multicolumn{6}{|c|}{ Total PSP } \\
\hline $5-12$ & $4.13(3.99)$ & $9.28(3.85)$ & $1.21(0.27)$ & $0.30(0.19)$ & $0.16(0.15)$ \\
\hline $26-36$ & $5.04(1.31)$ & $8.07(2.74)$ & $1.57(0.68)$ & $0.82(0.56)$ & $0.63(0.10)$ \\
\hline Both & $4.68(2.68)$ & 8.62 (3.38) & $1.42(0.58)$ & $0.58(0.50)$ & $0.42(0.27)$ \\
\hline
\end{tabular}

tent per cell did not vary with the external concentration of $\mathrm{PO}_{4}$ (Table 3 ). Thus a sufficient reservoir of phosphorus seems to have been available in all treatments to sustain the growth activity of cells. However, Sakshaug \& Holm-Hansen (1977) concluded that the point of change from N- to P-deficiency in cells would be PON:POP $=23$ for Skeletonema costatum and 45 for Pavlova lutheri, and Maestrini \& Kossut (1981) recorded PON:POP $=11.5$ to 19.7 in $\mathrm{N}$-deficient, and PON:POP $=31.8$ to 35.5 in $\mathrm{P}$ deficient cells of Thalassiosira pseudonana. Healey \& Hendzel (1980), who reviewed a large array of results, established that a PON:POP ratio $>43$ (atom:atom) reflects a severe phosphorus deficiency in the cell composition. Accordingly, the mean values of Alexandrium minutum grown in P-limiting media, $50.3(\mathrm{SD}=20.0$, $\mathrm{n}=30$ ) and $61.7(\mathrm{SD}=26.7, \mathrm{n}=30)$ (Fig. 1), would reflect a phosphorus deficiency in the cell content (sensu Healey \& Hendzel 1980).

Both the carbon, nitrogen and chl a contents in cells grown in the phosphorus-limiting conditions were significantly higher than those in cells grown in the nitrogen-limiting conditions: roughly twice as much carbon, and 3 times more nitrogen and chl a (Tables $2 \& 3$ ). Flynn et al. (1994) also observed that 'cells grown in low- $\mathrm{N}$ media had half the $\mathrm{C}$ content of those grown in the low-P media (0.6 vs $1.2 \mathrm{ng} \mathrm{C} \mathrm{cell}^{-1}$ )' (equal to 50 and 100 pmoly; that is almost exactly the difference we recorded: 82 and $168 \mathrm{pmol} \mathrm{C} \mathrm{Cell}^{-1}$ (mean values of the $2 \mathrm{~N}$ - and P-limiting treatments). Cells grown in the $\mathrm{N}: \mathrm{P}$ balanced condition showed a carbon content similar to cells grown in nitrogen-limiting conditions, while their nitrogen and chl a contents were in between those of cells grown in phosphorus- or nitrogen-limiting conditions. Our values for cells grown in P-limiting media

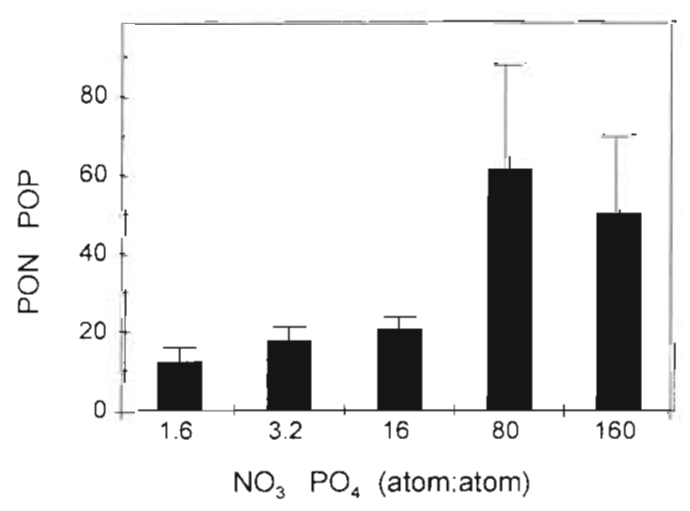

Fig. 1. Mean overall $(n=30)$ PON:POP (atom:atom) values in cells grown in semi-continuous regime in the 5 different $N: P$ conditions 
are higher than those reported by Flynn et al. (1994): 33 to $100 \mathrm{pmol} \mathrm{C} \mathrm{Cell}^{-1}$. We have no clear explanation for this difference. Perhaps there was more accumulation of thecal-plate $\mathrm{C}$ from dead cells in our cultures. However, our cells also contained somewhat more chl a than those of Flynn et al. (1994): from 2.5 to 8.7 and 1.5 to $7 \mathrm{pg} \mathrm{cell}^{-1}$, respectively.

According to Healey \& Hendzel (1980), a C:P >260 (atom:atom) reflects a severe phosphorus deficiency in the cell content, whereas a $\mathrm{C}: \mathrm{N}>14.3$ (atom:atom) would reflect a severe nitrogen deficiency. With regard to these values, cell contents of Alexandrium minutum grown under the $2 \mathrm{~N}: \mathrm{P}<16$ conditions should have been nitrogen-deficient, whereas contents of cells grown under the $2 \mathrm{~N}: \mathrm{P}>16$ conditions should have been phosphorus-deficient (Table 5), (sensu Healey \& Hendzel 1980).

Altogether, our results indicate that cells grown in the $2 \mathrm{~N}: \mathrm{P}<16$ conditions were in fact nitrogen-deficient, while it is unclear whether contents of cells grown in the $N: P=80$ and $N: P=160$ conditions were phosphorus-deficient in the full sense, namely that the cell metabolism was affected by a lack of phosphorus. However, the content of cells grown in the high N:P media was skewed towards an accumulation of carbon and nitrogen. Accordingly, we conclude a minima that cells were 'nitrogen-surfeit'.

The toxin content in cells also greatly changed according to the N:P ratio. The mean toxin content we obtained in cells grown in the N:P balanced condition, $1.24 \mathrm{fmol} \mathrm{cell}^{-1}(\mathrm{SD}=0.32, \mathrm{n}=34)$, and the 2 mean values we recorded in P-limiting conditions, $4.31 \mathrm{fmol} \mathrm{cell}^{-1}$ $(\mathrm{SD}=2.52, \mathrm{n}=34)$ and $8.01(\mathrm{SD}=2.96, \mathrm{n}=34)$ (Fig. 2$)$ fell into the range of the maximum value ( $5 \mathrm{fmol} \mathrm{cell}^{-1}$ ) reported, in similar high $\mathrm{N}: \mathrm{P}$ conditions, for a weakly toxic Alexandrium minutum strain (AL2V), whereas another more toxic strain (AL1V) showed PSP contents ranging from 15 to $40 \mathrm{fmol}^{\text {cell }}{ }^{-1}$ (Flynn et al. 1994).

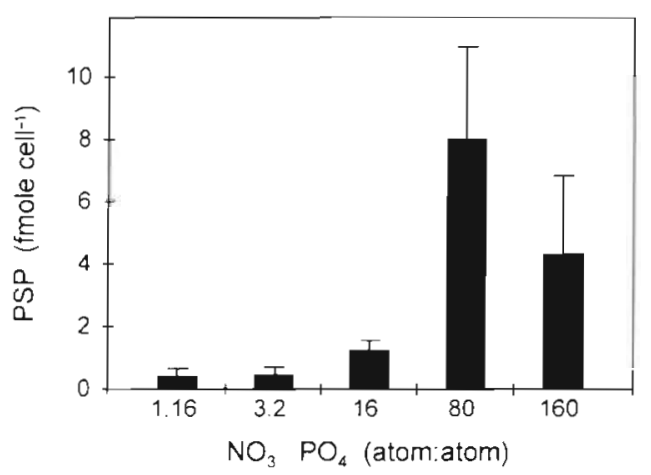

Fig. 2. Mean overall ( $\mathrm{n}=34$ or 35 ) PSP toxin content ( $\mathrm{fmol}$ cell ${ }^{-1}$ ) in Alexandrium minutum grown in semi-continuous regime in the 5 different $N: P$ conditions
Table 5. Mean POC:PON and POC:POP in Alexandrium minutum grown in the 5 different $N: P$ treatments. Numbers in parentheses are standard deviation; $\mathrm{n}=30$

\begin{tabular}{|lcc|}
\hline Treatment $(\mathrm{N}: \mathrm{P})$ & POC:PON & POC:POP \\
\hline 160 & $10.0(1.4)$ & $516(267)$ \\
80 & $8.9(1.0)$ & $560(285)$ \\
16 & $8.8(2.5)$ & $184(25)$ \\
3.16 & $15.0(1.4)$ & $266(32)$ \\
1.6 & $16.4(1.8)$ & $203(52)$ \\
\hline
\end{tabular}

In contrast, the low toxin content $\left(0.58\right.$ fmol cell $\left.{ }^{-1}\right)$ found in an Australian Alexandrium minutum strain grown on an N-limiting ( $\mathrm{N}: \mathrm{P}=10$ ) medium (Oshima et al. 1989) was in the range of our values obtained in $N$ limiting conditions, but differed in toxin composition. Important variations of toxin content in cells of Alexandrium species have been repeatedly reported. Waning or loss of toxicity of wild Alexandrium spp. cells, when isolated and cultured, is well documented (White 1986, Cembella et al. 1998). However, both strains of A. minutum that Flynn et al. (1994) and we used had been cultured for several years prior to both experiments. Moreover, the link between ageing and toxicity in $A$. minutum is not quite clear. The most toxic strain for Flynn et al. (1994) became almost non-toxic 3 yr after their experiments, in Swansea, while the formerly nontoxic strain became more toxic (Flynn pers. comm.). In contrast, in the same strains maintained in Vigo, the contents and compositions of toxins have not changed since their isolation (Reguera pers. comm.).

There is evidence for the genetic origin of variations in content and composition of toxins between strains. For instance, the geographic origin of such differences in Alexandrium spp. strains has been emphasized. A northwards increase of cell toxicity in $A$. fundyense and $A$. tamarense populations was reported along the north-western Atlantic coast (Maranda et al. 1985, Anderson et al. 1994) and strains of A. tamarense and A. catenella from different regions of Japan exhibited the same pattern with different toxin contents and compositions (Kim et al. 1993). There are no similar data available for $A$. minutum. However, some studies have reported dominance of GTX1 and GTX4 in A. minutum from Australia (Oshima et al. 1989), Galicia (Flynn et al. 1994) and the Balearic Islands (Forteza et al. 1998), whereas our strain showed dominance of GTX2 and GTX3 (Table 4). Hence, variation of toxin composition in A. minutum is an open question.

Phosphorus deficiency has been frequently reported to be associated with an increase in cell volume (Fuhs et al. 1972) and carbon content (Fuhs 1969). Likewise, Flyn et al. (1996) showed that Alexandrium minutum cells enlarged by up to $37 \%$ during prolonged P-depri- 
vation. Even such changes in the cell volume could not explain the ca 20 -fold higher toxin content in the $\mathrm{N}: \mathrm{P}>16$ conditions compared to the $\mathrm{N}: \mathrm{P}<16$ conditions we recorded; 8.0 and $0.4 \mathrm{fmol}_{\text {cell }}{ }^{-1}$, respectively. Moreover, although the standard deviations are large main values of the toxin content per carbon unit show the same trend; the lowest content in the N:P $<16$ condition was 6.5 fmol PSP nmol $C^{-1}(S D=2.6, n=27)$ whereas in the $\mathrm{N}: \mathrm{P}=16$ condition it was 3.3 times higher with $21.8 \mathrm{fmol}$ PSP nmol $\mathrm{C}^{-1}$ (SD $=11.0, \mathrm{n}=27$ ) and 9 times higher in the N:P $>16$ condition with $59.0 \mathrm{fmol}$ PSP nmol $C^{-1}(S D=28.0, n=26)$. The possible accumulation of $\mathrm{C}$ from thecal plates is not likely to have biased the toxin per carbon unit calculation, since all cultures were gently shaken; thus the plates, if any, were eliminated at the same dilution rate than the motile cells. In addition, during the second period, in the $\mathrm{N}: \mathrm{P}=160$ medium, cells grew at 0.22 division $\mathrm{d}^{-1}$ whilst those growing in the N:P $=1.6$ medium grew at 0.14 division $\mathrm{d}^{-1}$; hence, one would have expected to have more dead cells in the nitrogen-limiting media than in the phosphorus-limiting media, which was not observed. Therefore, we conclude that cells growing in high N:P media did indeed synthesise PSP toxins more actively.

This finding differs somewhat from that of Flynn et al. $(1994,1995)$, who reported that toxin synthesis and toxin content on a cell or biomass basis in Alexandrium minutum declined during $\mathrm{N}$ or $\mathrm{P}$ deprivation. However, they also observed that P-stress followed by $\mathrm{N}$ stress did not result in such a decline, and thus they concluded that phosphorus was implicated in the regulation of toxin metabolism. The different experimental designs might partly explain this discrepancy. In Flynn et al.'s $(1994,1995)$ experiments, A. minutum was grown in batch culture, in the presence of high initial $\mathrm{NO}_{3}$ and $\mathrm{PO}_{4}$ concentrations. All the highest toxin contents per cell were recorded in the early stages, when only a fraction of the nutrient reservoirs had been taken up. In contrast, during our experiments, cells exhausted daily the reservoir of the limiting nutrient in the culture media; at the time of all the cell harvests, concentrations of the limiting nutrients were below the detection levels. Altogether, as discussed above, we assume that $A$. minutum grew in conditions which led to either acute nitrogen-deficient or nitrogen-surfeit cells.

PSP toxins are nitrogen-rich molecules which might be synthesised as a by-product of surplus amino acids or nitrogen excess at large. As a result, phosphorus deficiency has been shown to increase greatly the cell toxin contents compared to nutrient-balanced or $\mathrm{N}$ deficient conditions, either in Alexandrium catenella (Matsuda et al. 1996, Siu et al. 1997), A. excavatum (Levasseur et al. 1995), A. fundyense (Anderson et al.
1990) and A. tamarense (Boyer et al. 1987, Anderson et al. 1990), or Gymnodinium catenatum (Reguera \& Oshima 1990). Hence, the increase in toxin contents has been attributed to a mechanism for storing the nitrogen excess (Reguera \& Oshima 1990). Altogether our results for $A$. minutum agree with mechanisms well-known for other toxic dinoflagellates.

Acknowledgements. This study was supported by the European Community Program 'MAST' (contract number MAS3CT97-0103; NUTOX). We thank Dr Evelyne Erard-Le Denn (IFREMER Brest Centre, Brest, France) for kindly providing the cultured strain of Alexandrium minutum, Captain Lebourdiec and his crew of the 'Gabian' (Affaires Maritimes) for providing large volumes of offshore water, Mrs Céline Vérité for skilful technical assistance, Dr Kevin Flynn and Dr Beatriz Reguera for providing unpublished information, and 3 anonymous referees, who greatly helped to improve the manuscript.

\section{LITERATURE CITED}

Aminot A, Chaussepied M (1983) Manuel des analyses chimiques en milieu marin. CNEXO, BNDO/Documentation, Brest.

Anderson DM, Kulis DM, Sullivan JJ, Hall S, Lee C (1990) Dynamics and physiology of saxitoxin production by the dinoflagellates Alexandrium spp. Mar Biol 104:511-524

Anderson DM, Kulis DM, Doucette GJ, Gallagher JC, Balech E (1994) Biogeography of toxic dinoflagellates in the genus Alexandrium from the northeastern United States and Canada. Mar Biol 120:467-478

Balode M, Purina I, Béchemin C. Maestrini SY (1998) Effects of nutrient enrichment on the growth rates and community structure of summer phytoplankton from the Gulf of Riga, Baltic Sea. J Plankton Res 20:2251-2272

Bendschneider K, Robinson RJ (1952) A new spectrophotometric method for the determination of nitrite in sea water. J Mar Res 11:87-96

Boyer GL, Sullivan JJ, Andersen RJ, Harrison PJ, Taylor FJR (1987) Effects of nutrient limitation on toxin production and composition in the marine dinoflagellate Protogonyaulax tamarensis. Mar Biol 96:123-128

Brand LE, Guillard RRL, Murphy LS (1981) A method for the rapid and precise determination of acclimated phytoplankton reproduction rates. J Plankton Res 3:193-201

Bratbak G, Dundas I (1984) Bacterial dry matter content and biomass estimation. Appl Environ Microbiol 48:755-757

Brzezinski MA (1985) The Si:C:N ratio of marine diatoms: interspecific variability and the effect of some environmental variables. J Phycol 21:347-357

Cembella AD, Therriault JC, Beland P (1988) Toxicity of cultured isolates and natural populations of Protogonyalaux tamarensis from the St. Lawrence estuary. J Shellfish Res 7:611-621

Coleman AW (1980) Enhanced detection of bacteria in natural environments by fluorochrome staining of DNA. Limnol Oceanogr 25:948-951

Conley DJ, Schelske CL, Stoermer EF (1993) Modification of the biogeochemical cycle of silica with eutrophisation Mar Ecol Prog Ser 101:179-192

Dippner JW (1998) Competition between different groups of phytoplankton for nutrients in the southern North Sea. J Mar Sys 14:181-198 
Droop MR (1974) The nutrient status of algal cells in continuous culture. J Mar Biol Assoc UK 54:825-855

Egge JK, Aksnes DL (1992) Silicate as regulating nutrient in phytoplankton competition. Mar Ecol Prog Ser 83:281-289

Flynn K, Flynn KJ, Jones KJ (1993) Change in dinoflagellate intracellular amino acids in response to diurnal changes in light and N supply. Mar Ecol Prog Ser 100:245-252

Flynn K, Franco JM, Fernandez P, Reguera B, Zapata $M$, Wood G, Flynn KJ (1994) Changes in toxin content, biomass and pigments of the dinoflagellate Alexandrium minutum during nitrogen refeeding and growth into nitrogen or phosphorus stress. Mar Ecol Prog Ser 111:99-109

Flynn $K_{1}$ Franco J, Fernandez P, Reguera B, Zapata M, Flynn KJ (1995) Nitrogen and phosphorus limitation in cultured Alexandrium minutum Halim does not promote toxin production. In: Lassus P, Arzul G, Erard-Le Denn E, Gentien $P$, Marcaillou-Le Baut $C$ (eds) Harmful marine algal blooms. Lavoisier, Paris, p 439-444

Flynn K. Jnnes K.I: Flynn KJ (1996) Comparisons among species of Alexandrium (Dinophyceae) grown in nitrogen- or phosphorus-limiting batch culture. Mar Biol 126:9-18

Forteza V, Quetglas G, Delgado M, Reyero MI, Fraga S, Franco JM, Cacho E (1998) Toxic Alexandrium minutum bloom in Palma de Mallorca harbour, (Balearic Islands), western Mediterranean). In: Reguera B, Blanco J, Fernandez ML, Wyatt T (eds) Harmful algae. Xunta de Galicia, Vigo; IOC-UNESCO, Paris, p 58-59

Fuhs GW (1969) Phosphorus content and rate of growth in the diatoms Cyclotella nana and Thalassiosira fluviatilis. J Phycol 5:312-321

Fuhs GW, Demmerle SD, Canelli E, Chen M (1972) Characterization of phosphorus-limited plankton algae. In: Likens GE (ed) Proceedings of nutrients and eutrophication: the limiting-nutrient controversy. Limnol Oceanogr Spec Symp I:113-133

Guillard RRL, Ryther JH (1962) Studies on marine planktonic diatoms I. Cyclotella nana Hustedt and Detonula confervacea (Cleve) Gran. Can J Microbiol 8:229-239

Hall S (1982) Toxins and toxicity of Protogonyaulax from the northeast Pacific. PhD thesis, University of Alaska, Fairbanks

Healey FP, Hendzel LL (1979) Indicators of phosphorus and nitrogen deficiency in five algae in culture. J Fish Res Board Can 36:1364-1369

Healey FP, Hendzel LL (1980) Physiological indicators of nutrient deficiency in lake phytoplankton. Can Bull Fish Aquat Sci 37:442-453

Hummert C, Ritscher M, Reinhardt K, Luckas B (1997) Analysis of characteristic PSP profiles produced by Pyrodinium bahamense and several strains of Alexandrium using HPLC based on ion-pair chromatographic separation, post-column oxidation and fluorescence detection. Chromatographia 45:312-316

Kim CH, Sako Y, Ishida Y (1.993) Comparison of toxin composition between populations of Alexandrium spp. from geographically distant areas. Nippon Suisan Gakkaishi 59:641-646

Koroleff F (1976) Determination of ammonia. In: Grasshoff K, Ehrhardt M, Kremling K (eds) Methods of seawater analysis. Verlag Chemie, Weinheim, p 126-133

Levasseur M, Gamache T, St.-Pierre I, Michaud S (1995) Does the cost of $\mathrm{NO}_{3}{ }^{-}$reduction affect the production of harmful compounds by Alexandrium excavatum? In: Lassus $\mathrm{P}$, Arzul G, Erard-Le Denn E, Gentien P, Marcaillou-Le Baut $C$ (eds) Harmful marine algal blooms. Lavoisier, Paris, p 463-468

Maestrini SY, Kossut MG (1981) In situ cell depletion of some marine algae enclosed in dialysis sacks and their use for the determination of nutrient-limiting growth in Ligurian coastal waters (Mediterranean Sea). J Exp Mar Biol Ecol 50:1-19

Maranda L, Anderson DM, Shimizu Y (1985) Comparison of toxicity between populations of Gonyaulax tamarensis of eastern North American waters. Estuar Coast Shelf Sci 21: 401-410

Matsuda A, Nishijima T, Fukami K (1996) Effects of nitrogen deficiency on the PSP production by Alexandrium catenella under axenic cultures. In: Yasumoto $T_{1}$ Oshima $Y$, Fukuyo $Y$ (eds) Harmful and toxic algal blooms. Intergovernmental Oceanographic Commission of UNESCO, Paris, p 305-308

Murphy J, Riley JP (1962) A modified single solution method for the determination of phosphate in natural waters. Analyt Chim Acta 27:31-36

Oshima Y, Hirota M, Yasumoto T, Hallegraeff GM, Blackburn SI. Steffensen DA (1989) Production of paralytic shellfish toxins by the dinoflagellate Alexandrium minutum. Nippon Suisan Gakkaishi 55:925

Porter KG, Feig YS (1980) The use of DAPI for identifying and counting aquatic microflora. Limnol Oceanogr 25:943-948

Pujo-Pay M, Raimbault P (1994) Improvement of the wet-oxidation procedure for simultaneous determination of particulate organic nitrogen and phosphorus collected on filters. Mar Ecol Prog Ser 105:203-207

Ragueneau O, De Blas Varela E, Tréguer P, Quéguiner B, Del Amo Y (1994) Phytoplankton dynamics in relation to the biogeochemical cycle of silicon in a coastal ecosystem of western Europe. Mar Ecol Prog Ser 106:157-172

Rahm L, Conley D, Sandén P, Wulff F, Stalnacke P (1996) Time series analysis of nutrient inputs to the Baltic Sea and changing DSi:DIN ratios. Mar Ecol Prog Ser 130: $221-228$

Redfield AC (1934) On the proportions of organic derivatives in sea water and their relation to the composition of plankton. In: Daniel RJ (ed) James Johnstone Memorial Volume. The University Press, Liverpool, p 176-192

Reguera B, Oshima Y (1990) Response of Gymnodinium catenatum to increasing levels of nitrate: growth patterns and toxicity. In: Granéli E, Sundström B, Edler L, Anderson DM (eds) Toxic marine phytoplankton. Elsevier Publ, New York, p 316-319

Sakshaug E, Holm-Hansen O (1977) Chemical composition of Skeletonema costatum (Grev.) Cleve and Pavlova (Monochrysis) lutheri (Droop) Green as a function of nitrate-, phosphate-, and iron-limited growth. J Exp Mar Biol Ecol 29:1-34

Sakshaug E, Granéli E, Elbrächter M, Kayser H (1984) Chemical composition and alkaline phosphatase activity of nutrient-saturated and P-deficient cells of four marine dinoflagellates. J Exp Mar Biol Ecol 77:241-254

Sandén P, Håkansson B (1996) Long-term trends in Secchi depth in the Baltic Sea. Limnol Oceanogr 41:346-351

Schelske CL, Stoermer EF (1972) Phosphorus, silica, and eutrophication of Lake Michigan. In: Likens GE (ed) Proceedings of nutrients and eutrophication: the limitingnutrient controversy, Limnol Oceanogr Spec Symp I: $157-171$

Schöllhorn E, Granéli E (1996) Influence of different nitrogen to silica ratios and artificial mixing on the structure of a summer phytoplankton community from the Swedish west coast (Gullmar Fjord). J Sea Res 35:159-167

Siu GKY, Young MLC, Chan DKO (1997) Environmental and nutritional factors which regulate population dynamics and toxin production in the dinoflagellate Alexandrium 
catenella. Hydrobiologia 352:117-140

Strickland JDH, Parsons TR (1972) A practical handbook of seawater analysis, 2nd edn. Bull Fish Res Board Can 167

Utermöhl H (1931) Neue Wege in der quantitativen Erfassung des Planktons. Verh Int Ver Limnol 5:567-596

Wasmund N, Nausch G, Matthaus W (1998) Phytoplankton spring blooms in the southern Baltic Sea-spatio-temporal development and long-term trends. J Plankton Res 20:1099-1117

Editorial responsibility: John Dolan,

Edgewater, Maryland, USA
White AW (1986) High toxin content in the dinoflagellate Gonyaulax excavata in nature. Toxicon 24:605-610

Yentsch CS, Menzel DW (1963) A method for the determination of phytoplankton and pheophytin by fluorescence. Deep-Sea Res 10:221-231

Yu RC, Hummert C, Luckas B, Qian PY, Zhou MJ (1998) Analysis of PSP toxins in algae and shellfish samples from China using a modified HPLC method. Chromatographia 48:671-676

Submitted: February 15, 1999; Accepted: July 3, 1999 Proofs received from author(s): November 11, 1999 